\title{
Article \\ Shielded Active Gas Forge Welding of an L80 Steel in a Small Scale Shielded Active Gas Forge Welding Machine
}

\author{
Vinothkumar Palanisamy ${ }^{1} \oplus$, Jan Ketil Solberg ${ }^{1, *}$ and Per Thomas Moe ${ }^{2}$ \\ 1 Department of Materials Science and Engineering, Norwegian University of Science and Technology, \\ Alfred Getz vei 2, 7034 Trondheim, Norway; vinothvp@gmail.com \\ 2 Department of Science and Industry Systems, University of South-Eastern Norway, Hasbergvei 36, Krona, \\ 3616 Kongsberg, Norway; Per.T.Moe@usn.no \\ * Correspondence: jan.ketil.solberg@ntnu.no
}

\section{check for}

updates

Citation: Palanisamy, V.; Solberg, J.K.; Moe, P.T. Shielded Active Gas Forge Welding of an L80 Steel in a Small Scale Shielded Active Gas Forge Welding Machine. J. Manuf. Mater. Process. 2021, 5, 16. https:// doi.org/10.3390/jmmp5010016

Received: 31 December 2020

Accepted: 4 February 2021

Published: 8 February 2021

Publisher's Note: MDPI stays neutral with regard to jurisdictional claims in published maps and institutional affiliations.

Copyright: (c) 2021 by the authors. Licensee MDPI, Basel, Switzerland. This article is an open access article distributed under the terms and conditions of the Creative Commons Attribution (CC BY) license (https:// creativecommons.org/licenses/by/ $4.0 /)$.

\begin{abstract}
The Shielded Active Gas Forge Welding (SAG-FW) method is a solid-state welding technique in which the mating surfaces are heated by induction heating or direct electrical heating before being forged together to form a weld. In this article, an API 5CT L80 grade carbon steel alloy has been welded using the SAG-FW method. A small-scale forge welding machine has been used to join miniature pipes extracted from a large pipe wall. The welding was performed at three different forging temperatures, i.e., $1300^{\circ} \mathrm{C}, 1150{ }^{\circ} \mathrm{C}$ and $950{ }^{\circ} \mathrm{C}$, in some cases followed by one or two post weld heat treatment cycles. In order to qualify the welds, mechanical and corrosion testing was performed on miniature samples extracted from the welded pipes. In addition, the microstructure of the welds was analysed, and electron probe microanalysis was carried out to control that no oxide film had formed along the weld line. Based on the complete set of experimental results, promising parameters for SAG-FW welding of the API 5CT L80 grade steel are suggested. The most promising procedure includes forging at relative high temperature $\left(1150{ }^{\circ} \mathrm{C}\right)$ followed by rapid cooling and a short temper. This procedure was found to give a weld zone microstructure dominated by tempered martensite with promising mechanical and corrosion properties. The investigation confirmed that small scale forge welding testing is a useful tool in the development of welding parameters for full size SAG-FW welding.
\end{abstract}

Keywords: L80 steel; solid state welding; shielded active gas forge welding; oil and gas

\section{Introduction}

Several solid-state welding techniques exist, e.g., cold forming, friction welding, diffusion bonding, explosive welding and forge welding, and several of these techniques have been used for joining steels for various applications [1-3]. Forge welding is one of the oldest solid-state joining techniques. Solid-state welding has several advantages over fusion welding and may often be preferable to fusion welding for several steel applications. There are advantages related to the absence of filler material and to the narrow heat affected zone (HAZ) that is normally obtained during fusion welding. The heat affected zone is a problem associated with welding because it is prone to produce complex microstructures as a result of a variety of peak temperatures and post weld cooling rates. Local formation of intermetallic components, carbides, nitrides and other brittle constituents in HAZ have been reported to reduce the fracture toughness of fusion welds [1,4-8]. Many of these reactions also occur in the heat affected zone adjacent to solid state welds, but the problem is less there than in fusion welds because during solid state welding, the highest temperatures near the melting temperature are avoided. During solid state welding, the high temperatures alter the base material microstructure, so challenges exist also for these welding methods, although the absence of filler material eliminates some of the metallurgical problems associated with welding. 
The Shielded Active Gas Forge Welding (SAG-FW) method is a solid-state welding technique. It was invented in the 1980s [9]. Since then the SAG-FW process has been developed and qualified for welding of offshore pipelines and casings of $0.2-0.5 \mathrm{wt} \% \mathrm{C}$ steels. In the SAG-FW process, the mating ends of the components (pipes) are heated to a temperature well below the melting point of the alloy(s) and then pressed together in one single operation to complete the joining process within a few seconds. Heating can be applied by induction or by direct resistive heating. A mixture of hydrogen and nitrogen is used as an active shielding gas to prevent oxidation during the entire process. This welding process is highly efficient due to short welding times. High carbon steel pipes that cannot be welded by conventional fusion welding methods, can be welded using the SAG-FW method. SAG-FW can include post-weld heat treatment using the same heating method as used for the welding operation. Although SAG-FW is an efficient welding method, testing and qualification of welded components are not cost effective. Optimization of the welding parameters requires an extensive experimental program. In order to conduct such experiments in a cost-effective manner, a small scale forge welding (SSFW) apparatus was developed by Ganesan et al. [10-12]. The design and mode of operation of this equipment is given in detail in [10]. Test specimens in the form of miniature pipes are machined from pipe material and welded together in the SSFW apparatus to test the effect of bevel design and forge welding parameters (temperature, compression length, and cooling rate) on the weld quality [9-13]. Several alloys satisfying API 5CT and API 5L have been welded by the SSFW method [11].

API 5CT describes standard technical specifications for casing and tubing pipes used in oil and gas well applications. L80 is a much-used grade with minimum yield strength $80 \mathrm{ksi}(552 \mathrm{MPa})$. Casing grades have traditionally not been made for welding, and some alloys satisfying requirements can be regarded as "unweldable" due to the need for time consuming heat treatment after welding. The present work is a systematic study on the use of SAG-FW for joining an alloy which base material satisfies the L80 requirements for well casings. Casing grades have proven difficult to join by most welding methods, e.g., the carbon contents of $0.2-0.5 \mathrm{wt} \%$ makes these steels hardly weldable or not weldable by traditional fusion welding due to the risk of brittle martensite formation in the heat affected zone. Threaded connectors are therefore usually used to join casing sections. However, threaded connections may leak, especially if they are deformed. The main reason for selecting forge welded connectors is that they can be more easily expanded downhole without leaking. Full scale SAG-FW machines have been developed for welding of oil well casing. The SSFW machine has been used to reduce development cost and time.

This work is partly based on previous works by the present authors [13-15], in which an L80 grade steel was thermally simulated in a SMITWELD thermal weld simulator to study the effect of peak temperature and cooling conditions typical of forge welding on the microstructure and mechanical and corrosion properties of the steel specimens. Such tests are even simpler and cheaper than SSFW tests since they do not include the forging stage of forge welding, but they are suitable to find auspicious heating and cooling conditions applied to SSFW specimens. The objective of the work is twofold. In a long perspective, the main objective is to confirm the ability of SSFW tests to generate reliable parameters for full scale SAG-FW welding. Next, in a more short-term perspective, an important aim of the work is to determine promising parameters for SAG-FW welding of the L80 casing grade steel that was investigated by the present authors in [14]. Promising temperature cycles arriving from the above mentioned SMITWELD simulations (or slight modifications of those cycles), will be applied in SSFW welding of miniature pipes machined from original tube walls of the L80 grade steel. The welded miniature pipes will then be subjected to a thorough weld qualification test program including determination of microstructure, hardness, ductility, toughness and corrosion properties in order to develop welding procedures that satisfy the API 5CT requirements [16] for sour service application in addition to giving acceptable corrosion resistance. According to API 5CT, the minimum tensile strength and maximum hardness of an L80 grade steel base material is $655 \mathrm{MPa}$ and $254 \mathrm{HV}$, 
respectively. The maximum hardness value is specified to prevent stress corrosion cracking. The minimum weld hardness to match the required minimum tensile strength of the steel would be $204 \mathrm{HV}$ according to tables for equivalent hardness and tensile strength, e.g., [17] Hardness values between $254 \mathrm{HV}$ and $204 \mathrm{HV}$ are thus required within the heat affected zone of a welded L80 grade steel. In addition, a minimum toughness value of $27 \mathrm{~J}$ is required for the weld (including HAZ) according to API 5CT.

\section{Materials and Methods}

\subsection{As-Received Steel}

The applied L80 casing grade steel was produced by OAO Volzhsky Pipe Plant (Volgograd, Russia). Its chemical composition is given in Table 1, measured by Mis Mechanical Ltd. (Consett, UK), by optical emission spectroscopy. The carbon contents of the steel is $0.24 \%$, its carbon equivalent is 0.53 [18], and its $\mathrm{Ac}_{1}$ and $\mathrm{Ac}_{3}$ temperatures were calculated to be $720^{\circ} \mathrm{C}$ and $827^{\circ} \mathrm{C}$, respectively [19]. The steel was received as $244 \mathrm{~mm}$ outer diameter pipes with a wall thickness of $11 \mathrm{~mm}$. Its microstructure was tempered martensite with a $0.2 \%$ proof strength of $589 \mathrm{MPa}$, a tensile strength of $727 \mathrm{MPa}$ (corresponding to a hardness of $227 \mathrm{HV}$ ), and an elongation of 30.2\%, all measured by Mis Mechanical Ltd. (Consett, UK).

Table 1. Chemical composition of the L80 grade steel, in $\mathrm{wt} \%$.

\begin{tabular}{cccccccccccc}
\hline Element & $\mathbf{C}$ & $\mathbf{S i}$ & $\mathbf{M n}$ & $\mathbf{P}$ & $\mathbf{S}$ & $\mathbf{C r}$ & $\mathbf{N i}$ & $\mathbf{C u}$ & $\mathbf{A l}$ & $\mathbf{M o}$ & $\mathbf{V}$ \\
\hline $\mathrm{wt} \%$ & 0.24 & 0.39 & 1.37 & 0.011 & 0.005 & 0.14 & 0.14 & 0.20 & 0.01 & 0.02 & 0.005 \\
\hline
\end{tabular}

\subsection{SSFW Welding}

Miniature pipe specimens were extracted from the original large-scale pipe wall in the longitudinal direction of the original tube. The miniature pipes were $95 \mathrm{~mm}$ long and were machined to $8 \mathrm{~mm}$ outer diameter (OD) and $2 \mathrm{~mm}$ wall thickness, Figure 1a. The pipe ends were machined to the bevel shape shown in Figure 1a. The bevel shape determines the inner and outer weld caps when the mating surfaces are pressed together. Several ABAQUS $^{\odot}$ simulations were carried out for different bevel shapes and forging parameters to achieve proper inner and outer weld caps without any undercut. A bevel shape defined by a bevel width ratio BWR of 0.60 was selected for this study.

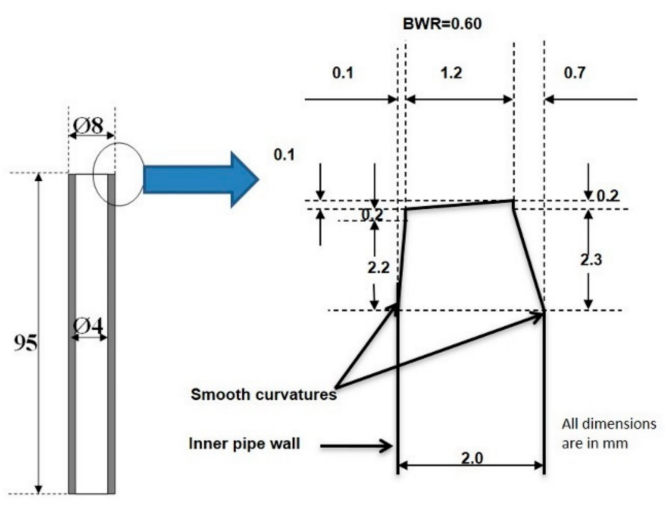

(a)



(b)

Figure 1. (a) Mating end dimensions of miniature pipes, (b) schematic drawing of welding set-up and process.

The design and mode of operation of the SSFW machine is given in detail in [10]. Figure $1 \mathrm{~b}$ shows a schematic drawing of the welding set-up and process. SAG-FW is a solid state welding method. The mating pipe ends have been beveled to allow for localized plastic deformation during forging. Heating was applied by induction, and the heating time to the forging temperature was $3.5 \mathrm{~s}$. A high temperature gradient is 
required to enforce local deformation. Temperature measurements were carried out by a thermocouple fixed $3 \mathrm{~mm}$ from one of the mating surfaces. A detailed discussion of the temperature distribution along the pipe axial direction is given in [13]. A mixture of hydrogen $(10 \%)$ and nitrogen $(90 \%)$ was introduced inside the pipes and flushed across the bevel as a reducing/protective gas. Gas flow rates of $17 \mathrm{~L} / \mathrm{min}$ during forging and $45 \mathrm{~L} / \mathrm{min}$ during subsequent cooling were used. The gap between the mating surfaces during heating, i.e., the root gap, was $2 \mathrm{~mm}$ during all welding experiments. The pipe ends were forged together immediately after the forging temperature was reached, applying a forge length of $2.7 \mathrm{~mm}$ from the first contact between the two surfaces. The forging speed was $17.9 \mathrm{~mm} / \mathrm{min}$. After forging, the pipes were immediately and rapidly cooled (quenched) to $900{ }^{\circ} \mathrm{C}$ and then subjected to different cooling conditions and post weld heat treatments.

Table 2 lists the different experimental conditions applied in the study. Quenching (Q) was obtained by applying a maximum gas flow as cooling medium. The cooling rate during quenching was approximately $45^{\circ} \mathrm{C} / \mathrm{s}$. After rapid cooling and quenching, most welds were tempered (martensite tempering, i.e., reduction of carbon supersaturation and annihilation of dislocations) for different holding times at $680{ }^{\circ} \mathrm{C}$ and subsequently quenched to room temperature. Two welds were given a short grain refining cycle to $950{ }^{\circ} \mathrm{C}$ before they finally were slowly cooled at $1{ }^{\circ} \mathrm{C} / \mathrm{s}$ to room temperature, introducing a normalizing effect. Weld W6 was given the most a complicated treatment, including both tempering and grain refinement. For multi-cycled specimens, the temperature was lowered to $200^{\circ} \mathrm{C}$, measured $3 \mathrm{~mm}$ from the mating surfaces, before the onset of the next cycle. Ten welded miniature pipes were produced for each thermal welding condition given in Table 2.

Table 2. Applied forging temperatures and cooling conditions. $Q=$ Quenched (at $45^{\circ} \mathrm{C} / \mathrm{s}$ ) after forging.

\begin{tabular}{cccc}
\hline Weld Number & $\begin{array}{c}\text { Forging } \\
\text { Temperature }\left[{ }^{\circ} \mathrm{C}\right]\end{array}$ & $\begin{array}{c}\text { Cooling Rate } \\
{\left[{ }^{\circ} \mathrm{C} / \mathrm{s}\right]}\end{array}$ & $\begin{array}{c}\text { Post Weld Heat Treatment } \\
\text { (Tempering/Grain Refinement) }\end{array}$ \\
\hline W1 & 1300 & 1 & - \\
\hline W2 & 1150 & 1 & - \\
\hline W3 & 950 & 1 & - \\
\hline W4 & 1300 & 10 & $950{ }^{\circ} \mathrm{C}-1 \mathrm{~s}-1{ }^{\circ} \mathrm{C} / \mathrm{s}$ \\
\hline W5 & 1300 & $\mathrm{Q}$ & $680^{\circ} \mathrm{C}-1 \mathrm{~s}^{\circ} \mathrm{C}-1 \mathrm{~s} 0^{\circ} \mathrm{C}-1 \mathrm{~s}-1{ }^{\circ} \mathrm{C} / \mathrm{s}$ \\
\hline W6 & 1300 & 10 & $680^{\circ} \mathrm{C}-1 \mathrm{~s}$ \\
\hline W7 & 1300 & 10 & $680^{\circ} \mathrm{C}-1 \mathrm{~s}$ \\
\hline W8 & 1150 & 10 & $680^{\circ} \mathrm{C}-300 \mathrm{~s}$ \\
\hline W9 & 1300 & $\mathrm{Q}$ & $680^{\circ} \mathrm{C}-1 \mathrm{~s}$ \\
\hline W10 & 1150 & $\mathrm{Q}$ &
\end{tabular}

\subsection{Metallography and Hardness Testing}

The welded pipes were cut, mechanically polished down to $1 \mu \mathrm{m}$ and finally etched in $2 \%$ Nital for microstructure analysis. Optical microscopy was carried out using a MEF4 microscope (Leica Microsystems, Wetzlar, Germany) attached with a ProgRes C10 CCD camera (Jenoptik, Jena, Germany). Grain sizes were measured by the linear intercept method [20].

One of the pipes that had been forge welded at $1300{ }^{\circ} \mathrm{C}$ and subsequently quenched (W5), was cut and polished down to $1 \mu \mathrm{m}$ for qualitative wave length dispersive (WDS) chemical microanalysis to reveal any presence of an oxide film along the weld line. For this purpose, qualitative oxygen $\mathrm{K}_{\alpha}$ line scans were performed across the weld line at several locations in a JXA-8500F electron microprobe analyser (JEOL, Tokyo, Japan) applying an LDE1 crystal, an acceleration voltage of $10 \mathrm{kV}$, a probe current of $40 \mathrm{nA}$, and a dwell 
time of $2 \mathrm{~s}$ at each analysed point. The distance between two neighbour analysed points was $0.24 \mu \mathrm{m}$. Hardness measurements were done by using a Leica VM HT MOT Vickers hardness tester applying $1 \mathrm{~kg}$ weight for $15 \mathrm{~s}\left(\mathrm{HV}_{1}\right)$. Each reported hardness value is the average of three individual measurements.

\subsection{Ductility Face Bend Testing}

Miniature test specimens extracted from forge welded pipes were face bend tested according to the ASTM E190 test procedure for guided bending [21]. The bend test specimens were machined from the forge welded pipes so that the weld zone was located in the middle of the specimens, and their dimensions were $1.5 \mathrm{~mm} \times 1.5 \mathrm{~mm} \times 40 \mathrm{~mm}$. The face bend tests were carried out using a $100 \mathrm{kN}$ servo hydraulic MTS 810 test machine with $6.3 \mathrm{~mm}$ punch roller diameter and $1 \mathrm{~mm} / \mathrm{min}$ punch speed, the outer weld face being in tension. Two specimens per weld condition were tested to a tensile strain value above 0.125 , which is required by API 5L. (Face bend testing is not included in the API 5CT requirements, so API 5L was used instead.) In one case, the two parallel test specimens broke before the required strain value was reached, and those tests were immediately interrupted as soon as failure occurred.

The face bent specimens were visually inspected in a Photomakroskop M400 for cracks (Wild, Heerbrugg, Switzerland). All face bent specimens were afterwards subjected to flat bend testing during which the specimens were first bent to $180^{\circ}$ and then fully deformed to flat condition. The flat bent specimens were also visually inspected for cracks.

\subsection{Toughness Testing and Thermal Weld Simulation}

Miniature Charpy V-notch specimens were machined from the forge welded pipes. Figure 2 shows the specimen dimensions. The specimens had a $0.3 \mathrm{~mm}$ deep notch with a root radius of $0.25 \mathrm{~mm}$ along the weld line, which is defined as the intersection between the specimen surface and the weld interface (contact surface between the mating surfaces). Two miniature specimens of each welding condition were tested at $0{ }^{\circ} \mathrm{C}$ in an impact testing machine (Otto Wolpert-Werke, Ludwigshafen/Rhein, Germany) with an impact load of $40 \mathrm{kpcm}$ (about $4 \mathrm{~J}$ ), an impact speed of $3.8 \mathrm{~m} / \mathrm{s}$, and an anvil distance of $20 \mathrm{~mm}$. No standard specimens were available for the small-scale toughness testing, but the machine was carefully adjusted according to ISO 148-2 with respect to 0-point swing of the pendulum and bearing friction. The testing was carried out in a temperature-controlled room. An impact testing temperature of $0^{\circ} \mathrm{C}$ is required by API 5CT.

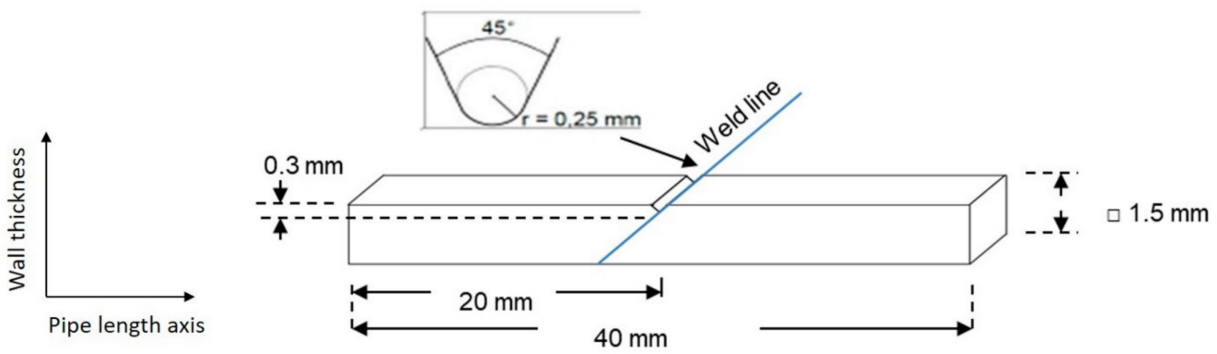

Figure 2. Miniature Charpy V-notch specimen. Weld interface is located vertically below the notch.

One objective of the present work is to compare weld zone toughness values obtained after SSFW welding with toughness values obtained after thermal weld simulation as reported by the present authors in [14]. However, three of the thermal conditions applied in the present work during forge welding were not included in the work of [14], i.e., the thermal conditions applied to the welds W5, W6 and W10. As a supplement to the investigation reported in [14], a set of half size weld simulation specimens of dimensions $100 \mathrm{~mm} \times 10 \mathrm{~mm} \times 5 \mathrm{~mm}$ were therefore machined from the L80 grade steel pipe wall in its longitudinal direction and thermally weld simulated at thermal conditions corresponding to those given to W5, W6 and W10 by using the same simulator as the one applied 
in Ref. [14] (SMITWELD Thermal Cycle Simulator (TCS) 1405, Lincoln Smitweld BV, Nijmegen, Netherlands). Four specimens were simulated at each condition. A detailed description of the experimental setup is given in [14] and is not repeated here. During all SMITWELD simulations, cooling from peak temperature was done in two steps, i.e., quenching down to $920^{\circ} \mathrm{C}$ followed by cooling to room temperature at different rates in order to simulate the cooling conditions of the SSFW tests. It should be mentioned, however, that while quenching during the SSFW tests was done at $45^{\circ} \mathrm{C} / \mathrm{s}$, quenching during the thermal weld simulation tests was done at $60^{\circ} \mathrm{C} / \mathrm{s}$. It is not believed that this difference is important. Half size Charpy V-notch specimens of dimensions $55 \mathrm{~mm} \times 10 \mathrm{~mm} \times 5 \mathrm{~mm}$ were machined from the thermally weld simulated specimens, two for each experimental condition, and toughness tested at $0^{\circ} \mathrm{C}$ in a RKD 450D Charpy V-notch pendulum impact tester (ZwickRoell LP, Kennesaw, GA, USA); anvil distance $45 \mathrm{~mm}$, impact speed $5.5 \mathrm{~m} / \mathrm{s}$ ). The obtained half size Charpy values were converted to full size values by dividing each half size value by 0.55 [22], as was also done in [14] to obtain full size values from half size values. In addition, miniature Charpy V-notch specimens were made from the remaining SMITWELD simulated specimens, two for each experimental condition. They had the same dimensions as the miniature specimens sketched in Figure 2, and they were toughness tested in the Otto Wolpert-Werke miniature Charpy V-notch machine under the same conditions as the SSFW specimens.

\subsection{Corrosion Testing}

Corrosion testing of welded miniature pipes was done by immersing longitudinal sections of the welded pipes in a $3.5 \mathrm{wt} \% \mathrm{NaCl}$ solution for $120 \mathrm{~h}$ at room temperature. Prior to the tests, the length sections were mechanically polished down to $1 \mu \mathrm{m}$, and the curved inner tube surface between the two wall sections was masked using a commercial paint. After the test, the specimens were cleaned with a soft sponge in running water to remove rust that had formed. The complete removal of rust by this method was confirmed by secondary electron imaging combined with light element chemical analysis in a SU6600 scanning electron microscope (Hitachi, Naka, Japan) equipped with an XFlash energy dispersive X-ray detector (Bruker Nano, Berlin, Germany) operated at $20 \mathrm{kV}$. Both the corroded surface itself and a length section cut normal to the corroded surface were examined. The cleaned and dried specimens were analysed for surface topography due to corrosion, using an IFM G4 infinite focus light microscope (Bruker Alicona, Raaba, Austria) with a lateral resolution of $300 \mathrm{~nm}$. The topography was measured along a $0.7 \mathrm{~mm}$ wide line oriented normal to the weld line and starting and ending $10 \mathrm{~mm}$ from the weld line on either side.

\section{Results and Discussion}

\subsection{General}

Figure 3 shows a typical length section of a welded pipe. The applied bevel design is seen to have produced a smooth outer cap and an inner cap with a small undercut in the weld zone WZ. An increase in the pipe thickness had occurred in the weld zone. The reason for this is the difficulty in limiting the width of the thermal zone for small specimens, leading to a broad deformation zone which causes the pipe wall to bend outwards. The undercut is also attributed to the long thermal zone of the small-scale weld samples.

Figure 4 shows the temperature prior to the forging step at different distances from the mating surface along the longitudinal axis of the pipe. These temperatures were measured by heating a specimen to different forging temperatures while measuring the temperature with thermocouples fixed at distances of $0.5,3,5$ and $7 \mathrm{~mm}$ from the mating surface. $\mathrm{The} \mathrm{Ac}_{3}$ temperature for the L80 casing grade steel was calculated to be $827^{\circ} \mathrm{C}$. Figure 4 clearly shows that, before forging, the $\mathrm{Ac}_{3}$ temperature was achieved at a distance of 7 $\mathrm{mm}$ from the mating surface for the pipe that was welded at $1300{ }^{\circ} \mathrm{C}$ forging temperature. Higher temperatures produced wider thermal zones than what lower temperatures did. It is believed that a reasonable estimate of the width of the heat affected zones can be 
obtained from the temperature graphs in Figure 4, which is seen by comparing Figure 4 with the hardness plots in Section 3.3. The reason for the good correspondence between the temperature profiles of Figure 4 and the hardness plots for the same temperatures is that the temperature plots at any distance from the weld line probably represent the maximum temperature that was obtained during the welding process. One reason for this is that no temperature increase is generally expected to occur due to the forging step, which is initiated a fraction of a second after the heating is turned off. During that time, a temperature drop of 50-100 K occurs due to significant heat conduction, radiation and convection at high temperatures, Moreover, since plastic deformation is only localized to the weld zone (and partly to the transition zone), it occurs at relatively high temperature at which the flow stress is low and little deformation heat is generated. Another reason why the local temperatures should not increase above the values given in Figure 4, is that the temperature gradient of each graph is relatively gentle, and more gentle the higher the temperature is, so heat should not be transferred so fast to cooler adjacent regions that a temperature increase should occur there. Therefore, the temperature graphs are assumed to define the heat affected zones of the welded specimens quite well, and to some degree also define the microstructures that can be expected there, although these microstructures also will strongly depend on the local cooling rate. The end of the intercritical zone ICZ should roughly be identified by the localization of the $\mathrm{Ac}_{1}$ temperature $\left(720^{\circ} \mathrm{C}\right)$ on the profiles. The heat affected zone continues somewhat outside ICZ where tempering of the base metal will continue to some degree, but not at long distances since the martensite was strongly tempered at the steel plant.



Figure 3. Length section of a welded pipe etched with $2 \%$ Nital, $W Z=$ Weld Zone, $T Z=$ Transition Zone, ICZ = InterCritical Zone (base metal heated to a temperature between $\mathrm{Ac}_{1}$ and $\mathrm{Ac}_{3}$ ), $\mathrm{BM}=$ Base Metal.

In line with the above discussion the forge weld in Figure 3 can be divided into three different zones, i.e., the weld zone $\mathrm{WZ}$, the transition zone $\mathrm{TZ}$ and the intercritical zone ICZ. WZ is the zone where the highest temperatures and strains were involved. The weld line is located in the middle of the weld zone, but it cannot be seen, neither in Figure 3 nor in most high magnification micrographs recorded from the region around the weld line (Section 3.2.1). 


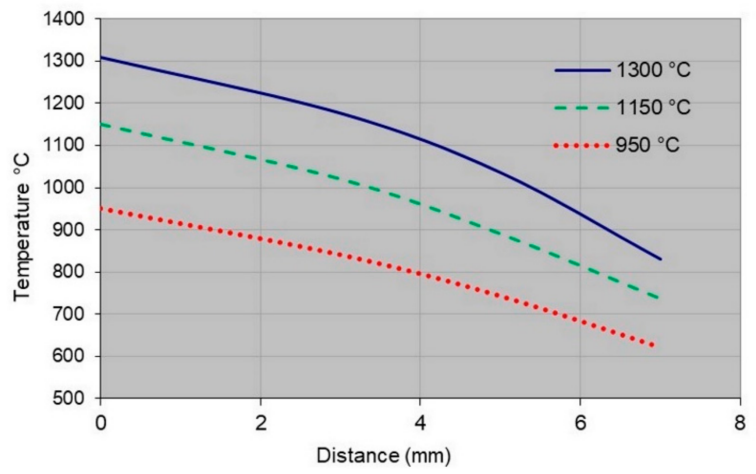

Figure 4. Temperature gradient along the longitudinal axis of the pipes prior to forging for different welding temperatures.

Figure 5 shows one of a number of qualitative WDS OK $\mathrm{W}_{\alpha}$ line scans that were acquired across the weld line of weld W9. The line scan shows an oxygen peak from an oxide particle $0.5 \mathrm{~mm}$ away from the weld line, but no oxygen was detected at the weld line itself, neither in this nor in the other line scans. The reason why no oxide film had formed at the weld line is that utmost care was taken to avoid oxidation of the mating surfaces during the welding experiments.



Figure 5. WDS oxygen $\mathrm{K}_{\alpha}$ line scan across the weld line of specimen W9.

\subsection{Microstructures}

\subsubsection{Weld Line/Zone}

Microstructures around the weld line from all eleven welds that are listed in Table 2, are shown in Figures 6 and 7, forging temperatures $1300^{\circ} \mathrm{C}$ and $1150 / 950{ }^{\circ} \mathrm{C}$, respectively. For the highest forging temperatures $1300^{\circ} \mathrm{C}$ and $1150{ }^{\circ} \mathrm{C}$, a coarse prior austenite grain structure had formed in the weld zone. The prior austenite grain size decreased away from the weld line as a consequence of the temperature gradients plotted in Figure 4. After forging at $1300{ }^{\circ} \mathrm{C}$, the average austenite grain size was about $45 \mu \mathrm{m}$ close to the weld line. For comparison, a heating cycle to $1300^{\circ} \mathrm{C}$ in the SMITWELD thermal weld simulator (no deformation involved) produced an average austenite grain size of about $80 \mu \mathrm{m}$ [14]. Thus, the forging step during the small-scale forge welding resulted in an almost halving of the average austenite grain size due to grain refinement caused by recrystallization. 

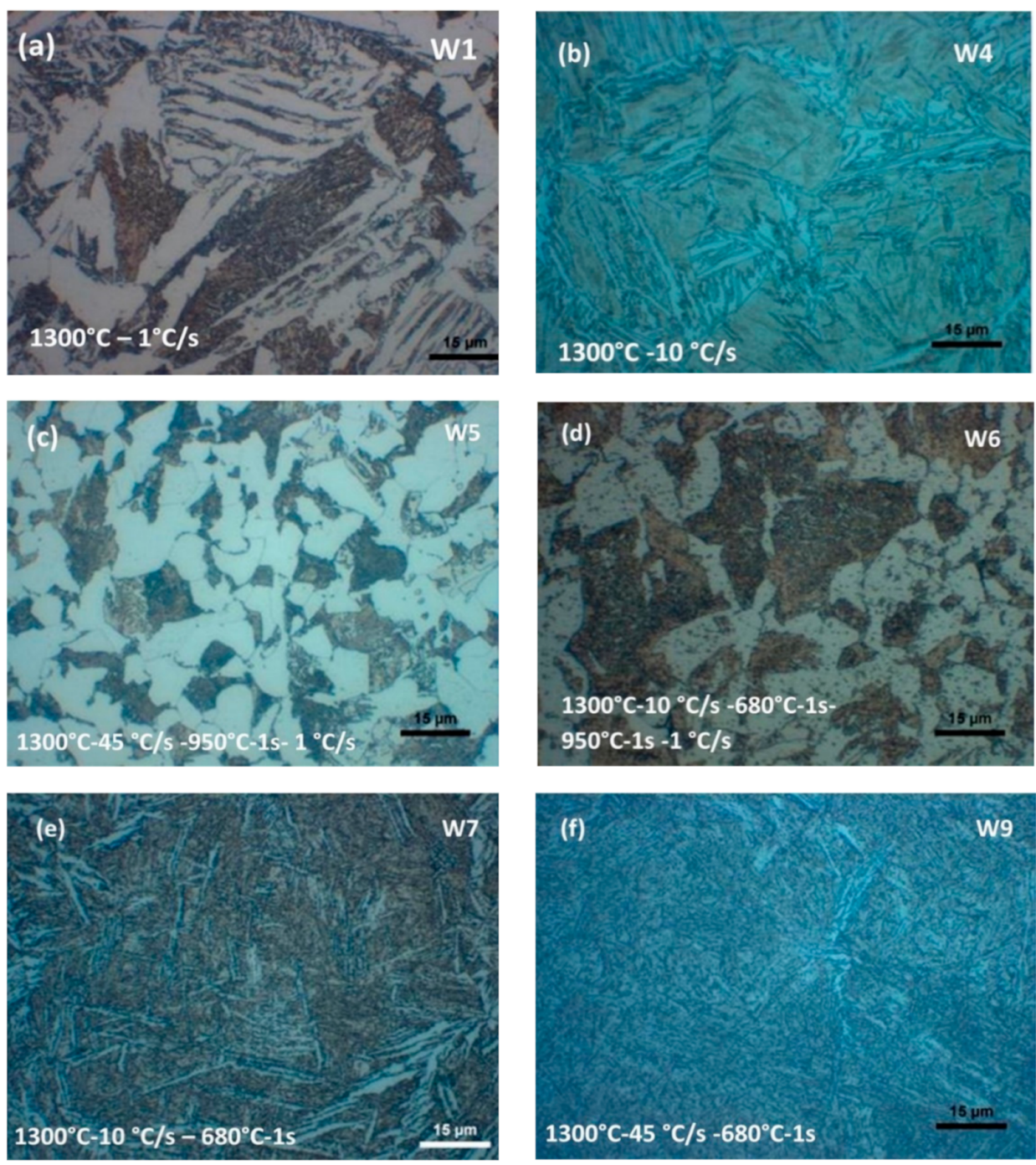

Figure 6. Weld zone microstructures of pipes forge welded at $1300{ }^{\circ} \mathrm{C}$. The cooling rates below $900{ }^{\circ} \mathrm{C}$ and additional heat treatment cycles are given at the bottom of the micrographs. The weld line is located vertically in the middle of each micrograph, in most cases not visible. Martensite is coloured light brown.

Welds W1, W2, W3 and W4 are the only welds that were not post weld heat treated after the welding cycle, of these welds, W1, W2 and W3 were cooled from the forging temperature at the lowest cooling rate $\left(1{ }^{\circ} \mathrm{C} / \mathrm{s}\right)$. Weld $\mathrm{W} 1$ was produced at $1300{ }^{\circ} \mathrm{C}$, and its weld zone/line contained a very coarse microstructure of grain boundary ferrite, Widmanstätten ferrite and pearlite, Figure $6 \mathrm{a}$. Weld W2 was produced at $1150{ }^{\circ} \mathrm{C}$ and had a similar microstructure to weld $\mathrm{W} 1$, but finer (due to a smaller prior austenite grain size, 20-40 $\mu \mathrm{m}$ ), Figure 7a. Weld W3 was produced at $950{ }^{\circ} \mathrm{C}$, and due to this low temperature, its prior austenite grain size was much smaller $(10-20 \mu \mathrm{m})$ than for the other two welds, resulting in a relatively fine-grained and normal ferrite/pearlite microstructure, Figure 7e. Weld 4 , on the other hand, were rapidly cooled from the forging temperature $1300{ }^{\circ} \mathrm{C}$, and this weld contained a microstructure of bainite and untempered martensite, Figure 6b.

The remaining welds were post weld heat treated after the welding cycle, in most cases only tempered at $680{ }^{\circ} \mathrm{C}$, but for two welds, a grain refining cycle at $950{ }^{\circ} \mathrm{C}$ was applied (without or in addition to tempering). The tempering cycles at $680{ }^{\circ} \mathrm{C}$ is not expected to have given any changes in microstructure that is easily recognizable in the optical micrographs of Figures 6 and 7, other than precipitation of small carbides that in some cases can be seen. Otherwise, the microstructures are expected to look the same as 
they were after cooling from forging temperature. Specimens that were quenched from high temperature and only tempered at $680{ }^{\circ} \mathrm{C}$ (i.e., W9, W10, W11), obtained a very fine tempered martensitic microstructure with some grain boundary ferrite and possibly some bainite in the weld zone, Figures $6 \mathrm{f}$ and $7 \mathrm{c}, \mathrm{d}$. Decreasing the cooling rate from $45^{\circ} \mathrm{C} / \mathrm{s}(\mathrm{Q})$ to $10^{\circ} \mathrm{C} / \mathrm{s}(\mathrm{W} 7, \mathrm{~W} 8)$ introduced more grain boundary ferrite and bainite in the microstructure, Figures $6 \mathrm{e}$ and $7 \mathrm{~b}$. The two welds that were slowly cooled at $1{ }^{\circ} \mathrm{C} / \mathrm{s}$ from $950{ }^{\circ} \mathrm{C}$ as the final welding stage, either without a prior temper (W5) or after a short temper at $680{ }^{\circ} \mathrm{C}$, contained a mixture of globular ferrite and pearlite in the weld zone, Figure $6 \mathrm{c}, \mathrm{d}$, respectively. Due to high temperature grain coarsening, the ferrite/pearlite microstructure was coarser in welds W5 and W6 that had been forged at $1300{ }^{\circ} \mathrm{C}$ prior to the final reheating to $950^{\circ} \mathrm{C}$, than in the weld that had been cooled directly from a forging temperature of $950^{\circ} \mathrm{C}(\mathrm{W} 3)$, Figure $7 \mathrm{e}$.
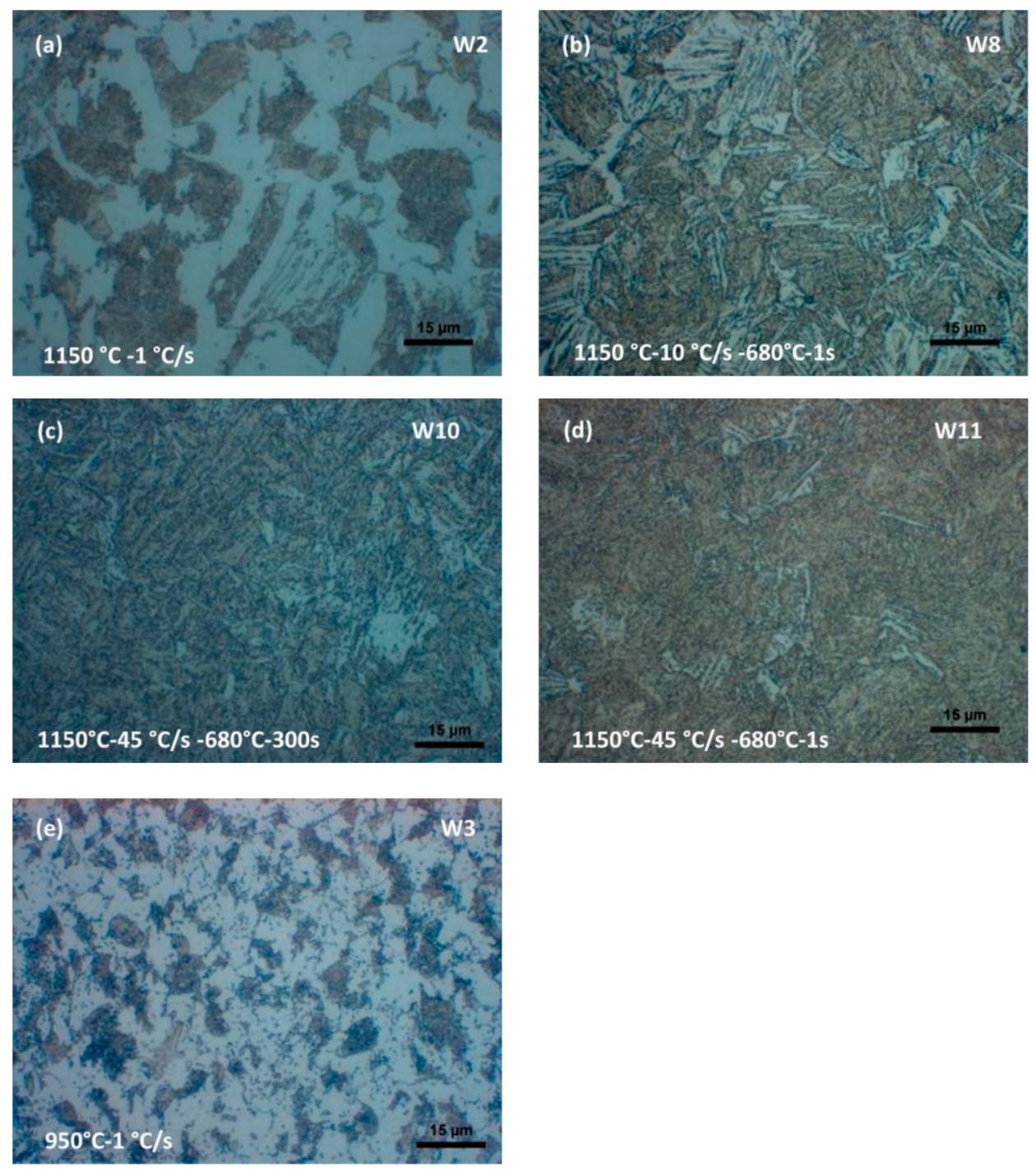

Figure 7. Weld zone microstructures of pipes forge welded at $1150{ }^{\circ} \mathrm{C}(\mathbf{a}-\mathbf{d})$ and $950{ }^{\circ} \mathrm{C}(\mathbf{e})$. The cooling rates below $900{ }^{\circ} \mathrm{C}$ and additional heat treatment cycles are given at the bottom of the micrographs. The weld line is located vertically in the middle of each micrograph, in most cases not visible. Martensite is coloured light brown.

\subsubsection{Heat Affected Zone}

The microstructure varied away from the weld line through the transition zone and the heat affected zone. Since the hardness measurements showed a drop in hardness 
3-7 mm from the weld line (see Section 3.3), the microstructure was studied closer at a distance of $5 \mathrm{~mm}$ from the weld line. At this position, mainly two kinds of microstructure existed, dependent on the temperature history during welding. The welds that had been produced by forging at $1300{ }^{\circ} \mathrm{C}$ and $1150{ }^{\circ} \mathrm{C}$ and cooled at the two highest cooling rates and not reheated to $950{ }^{\circ} \mathrm{C}$ (W4, W7-W11), had a very fine-grained ferritic microstructure at the location $5 \mathrm{~mm}$ from the weld line, see Figure $8 \mathrm{a}$ which shows the microstructure of W10 that had been welded at $1150{ }^{\circ} \mathrm{C}$. The presence of fine-grained ferrite $5 \mathrm{~mm}$ away from the weld line agrees well with the temperature profiles of Figure 4 . The profiles for $1150{ }^{\circ} \mathrm{C}$ and $1300{ }^{\circ} \mathrm{C}$ show that the pipes that were welded at these temperatures, were heated to temperatures above $\mathrm{Ac}_{3}\left(827^{\circ} \mathrm{C}\right)$ at locations $5 \mathrm{~mm}$ away from the weld line, The (relatively) fine-grained austenite that was formed at these temperatures, would then transform to fine-grained ferrite during the fast subsequent cooling. (In fusion welding terminology, this part of the heat affected zone is called "fine-grained HAZ".) Due to austenite grain growth, the specimens that had been forge welded at $1300^{\circ} \mathrm{C}$, contained a fine-grained ferrite that was coarser than the one shown in Figure 8a.

In most other cases, a more normal ferrite/pearlite microstructure was present at locations $5 \mathrm{~mm}$ away from the weld line, see Figure $8 \mathrm{~b}$ which shows the microstructure of W5 at this location. Of these welds, W1 $\left(1300^{\circ} \mathrm{C}\right)$ and $\mathrm{W} 2\left(1150{ }^{\circ} \mathrm{C}\right)$ had been cooled very slowly after forging, transforming the austenite that had formed $5 \mathrm{~mm}$ away from the weld line to a normal ferrite/pearlite.

The other pipes that had a normal ferrite/pearlite microstructure $5 \mathrm{~mm}$ from the weld line, had been reheated to $950{ }^{\circ} \mathrm{C}$ as a final welding step (W5, W6). Both these specimens had been welded at $1300{ }^{\circ} \mathrm{C}$ and rapidly cooled or quenched to room temperature. After this treatment, they are expected to have contained fine-grained ferrite $5 \mathrm{~mm}$ away from the weld line. During the reheating of the weld zone to $950{ }^{\circ} \mathrm{C}$, the pipe temperature $5 \mathrm{~mm}$ from the weld line must have increased to a temperature above $\mathrm{Ac}_{3}$ due to the heat remaining in the pipes from the preceding temperature cycle(s), allowing a ferrite/pearlite microstructure to develop during the subsequent slow cooling (the pipes were only cooled to $200{ }^{\circ} \mathrm{C}$ (measured at a position $3 \mathrm{~mm}$ from the weld line) prior to the re-heating to $950{ }^{\circ} \mathrm{C}$ ).

Figure 3, shows a sample that had been was forge welded at $950{ }^{\circ} \mathrm{C}$ and slowly cooled $\left(1^{\circ} \mathrm{C} / \mathrm{s}\right)$ to room temperature, possessed a more complicated and mixed microstructure of relatively coarse $(\sim 10 \mu \mathrm{m})$ and fine-grained ferrite and a dispersion of carbides at a distance of $5 \mathrm{~mm}$ from the weld line (Figure 8c). From Figure 4 it is seen that the probable reason for this is that this part of the heat affected zone was heated to a temperature in the intercritical temperature range (ICZ), slightly above $A c_{1}$, during the welding process, causing a small volume fraction of fine new austenite grains to form and a heavy tempering of the remaining martensite. The new austenite grains are expected to have transformed to the coarsest ferrite grains in the final microstructure, and probably the heavy tempering of the remaining martensite caused recrystallization to fine-grained ferrite as well as carbide coarsening, both constituents being preserved to room temperature.

\subsection{Hardness}

Vickers $\mathrm{HV}_{1}$ hardness as a function of distance from the weld line is shown in Figures 9 and 10 for samples forged at $1300{ }^{\circ} \mathrm{C}$ and $1150 / 950{ }^{\circ} \mathrm{C}$, respectively. The unaffected base metal of tempered martensite is located outside the intercritical zone where the hardness has reached the value of the base metal, 6-7.5 $\mathrm{mm}$ from the weld line. The width of the heat effected zone decreased somewhat with decreasing forging temperature. For the welds forged at $1300{ }^{\circ} \mathrm{C}$, the unaffected base metal starts about 7-8 mm from the weld line, and for the weld forged at $1150{ }^{\circ} \mathrm{C}$ the unaffected base metal starts about $5-7 \mathrm{~mm}$ from the weld line. 

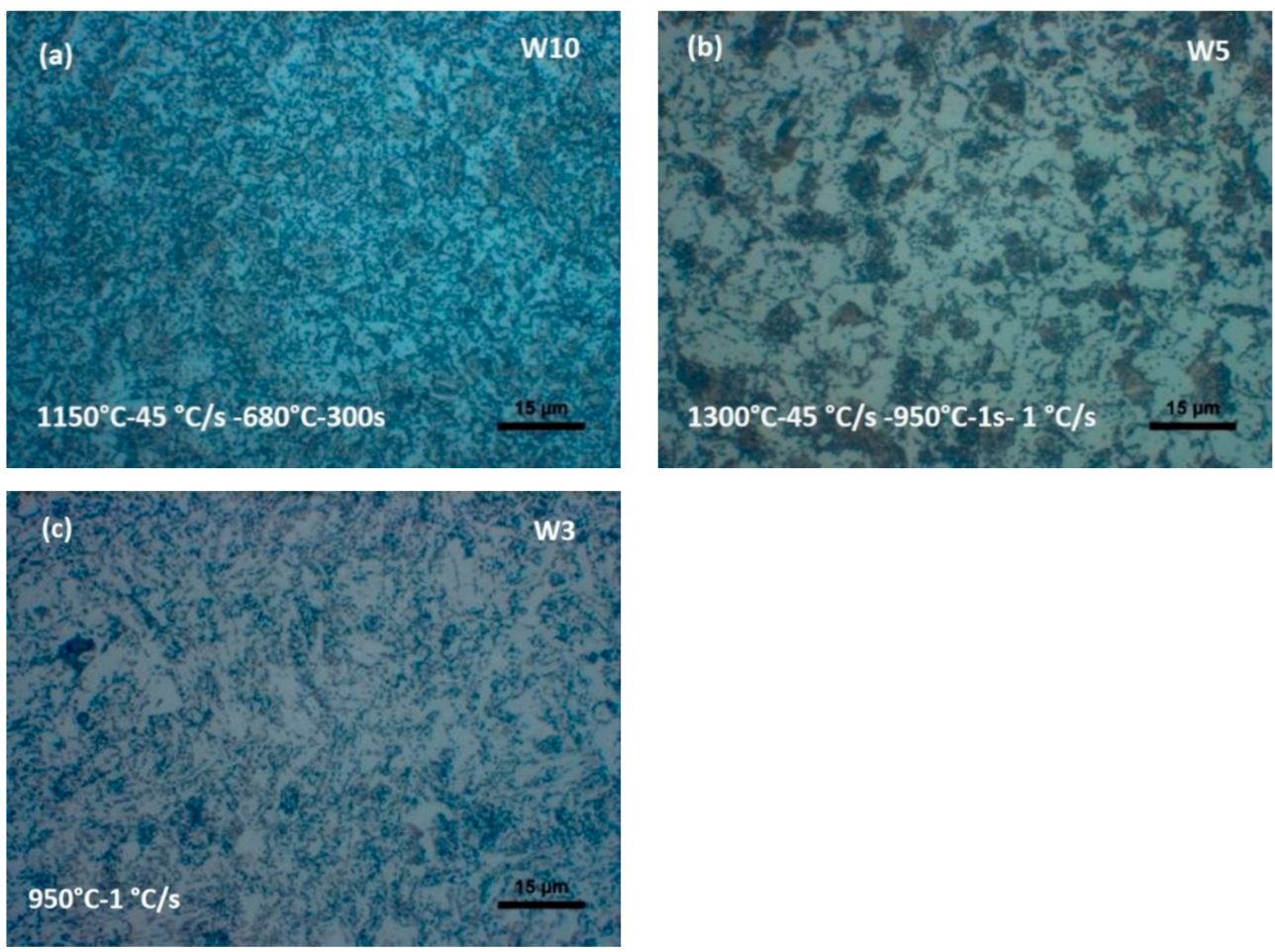

Figure 8. HAZ microstructures recorded $5 \mathrm{~mm}$ away from the weld line. (a) Very fine-grained ferrite in weld W10, (b) ferrite/pearlite in weld W5, (c) Mixture of relatively coarse and very fine ferrite in weld W3, probably ICZ microstructure.

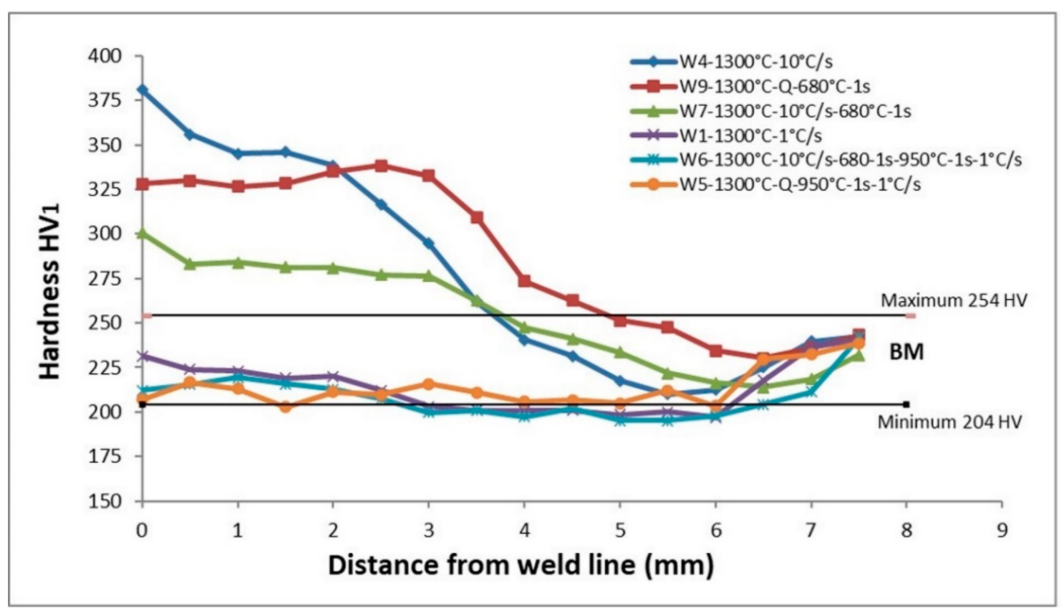

Figure 9. Hardness profiles of pipes forge welded at $1300^{\circ} \mathrm{C}$ followed by different thermal conditions. Base metal hardness is reached at a distance of $7.5 \mathrm{~mm}$ from weld line.

For all pipes, the highest hardness was observed in the weld zone, and the hardness in the heat affected zone decreased with increasing distance from the weld zone to the location of the unaffected base material. Weld W4 containing bainite and untempered martensite had the highest weld line hardness, Figure 9. According to the API 5CT requirements, the hardness values should be in the range 204-254 HV, see Section 1. Only weld W5 $\left(1300^{\circ} \mathrm{C}\right)$ fully meets this requirement over the whole heat affected zone. In addition, the $1300{ }^{\circ} \mathrm{C}$ welds $\mathrm{W} 1$ and $\mathrm{W} 6$, the $1150{ }^{\circ} \mathrm{C}$ welds $\mathrm{W} 2$ and $\mathrm{W} 8$, and the $950{ }^{\circ} \mathrm{C}$ weld $\mathrm{W} 3$ are close to fulfilling the hardness requirement (only one of the hardness values of weld W1 fails to meet the criterion). Except from W8, all these welds had been slowly cooled through the austenite to ferrite transformation range during the final stage of the welding process, and they contained a microstructure consisting of ferrite and pearlite. This microstructure 
gave a satisfactory low hardness in the weld zone. For these welds, the hardness was nearly unchanged throughout the whole heat affected zone. Most welds that had not been slowly cooled during the austenite-to-ferrite transformation, contained a microstructure consisting mainly of martensite in the weld zone, and even though subsequent tempering at $680{ }^{\circ} \mathrm{C}$ was applied for most of these welds, the martensite was too hard to fulfil the hardness requirement.

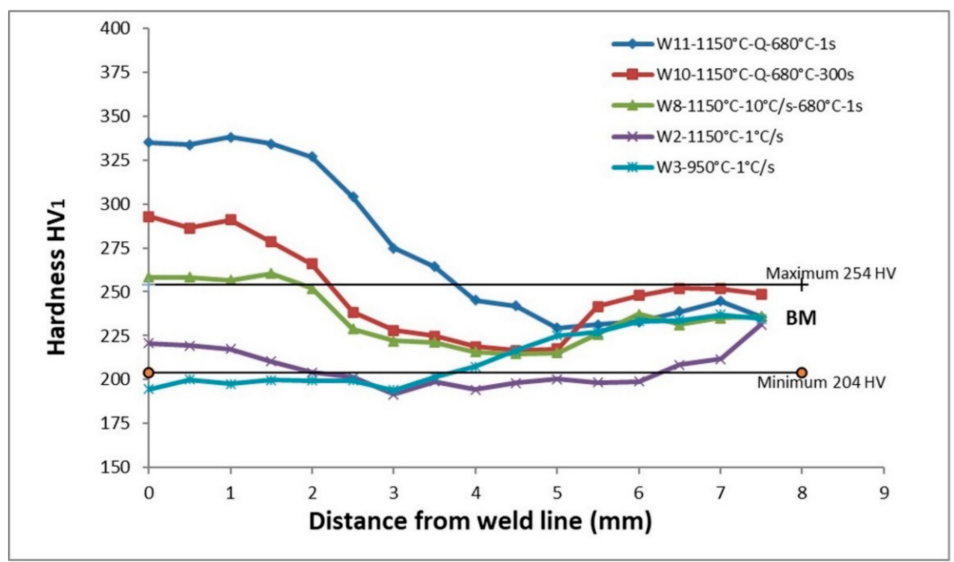

Figure 10. Hardness profiles of pipes forge welded at $1150{ }^{\circ} \mathrm{C}(\mathrm{W} 2, \mathrm{~W} 8, \mathrm{~W} 10, \mathrm{~W} 11)$ and $950{ }^{\circ} \mathrm{C}(\mathrm{W} 3)$ followed by different thermal conditions. Base metal hardness is reached at a distance of $6-7.5 \mathrm{~mm}$ from the weld line.

Of the welds that had been cooled at a medium cooling rate $\left(10{ }^{\circ} \mathrm{C} / \mathrm{s}\right), \mathrm{W} 8$ (hardness $258 \mathrm{HV}_{1}$ at the weld line) nearly satisfied the maximum hardness requirement, and only small adjustments of the welding parameters would probably bring this hardness to a value within the requirement. Weld $\mathrm{W} 8$ had been forged at $1150{ }^{\circ} \mathrm{C}$, so its prior austenite grain size was finer than in the specimens that had been forged at $1300^{\circ} \mathrm{C}$, and its weld zone contained fair amounts of grain boundary ferrite and bainite in addition to tempered martensite Figure $7 \mathrm{~b}$, compare with $\mathrm{W} 4$ that was forged at $1300{ }^{\circ} \mathrm{C}$ and cooled at the same rate Figure $6 b$, and with $W 11$ that was forged at the same temperature, but quenched directly from the forging temperature Figure $7 \mathrm{~d}$. The hardness of the welds that were cooled at a high (Q) or medium rate, was in most cases reasonably constant to a distance of 2-3 mm from the weld line. This is in agreement with observations of the microstructure that was fairly unchanged in the same area. However, a slight increase in the amount of grain boundary ferrite away from the weld line caused a certain hardness drop in the same direction.

Although weld W3 possessed an acceptable hardness and microstructure, the forging temperature was unfortunately not sufficiently high to provide the necessary material flow (due to a relatively high flow stress) to achieve good outer and inner weld caps for this weld. Figure 11 shows a macro image of the as welded W3 specimen. Even though a small undercut is expected at the inner cap, W3 had not a smooth outer cap either.

\subsection{Ductility of Weld Zone}

Figure 12 shows a typical face bent miniature weld specimen. For casing grade steels, the API 5L acceptance criterion for face bend tests is that no crack should be observed after bending to a minimum strain of 0.125 [23]. (API 5L is more relevant than API 5CT for bend tests). The miniature bend specimens were bent to a strain value that in average was 0.144 for the entire set of specimens, excluding the two parallels of weld W4 that broke before the critical strain was reached, see Figure 13 that shows one of the W4 parallels after interruption of the test. In none of the other welds was any crack detected after the bend test. Thus, all welds except W4 met the API 5L acceptance criterion. Moreover, no cracks were observed after the $180^{\circ}$ bending and the flat bend testing that were performed 
on all specimens that had passed the flat bend test. The failure of specimen W4 was not unexpected since it had the hardest weld zone microstructure of all welds $\left(381 \mathrm{HV}_{1}\right.$, forged at $1300{ }^{\circ} \mathrm{C}$, cooled at $10{ }^{\circ} \mathrm{C} / \mathrm{s}$, not tempered). Its microstructure consisted of a mixture of bainite and untempered martensite, both being very brittle constituents, Figure $6 \mathrm{~b}$. Weld W7 was welded at the same conditions as W4, but was shortly post-weld heat treated at $680^{\circ} \mathrm{C}$, and this tempering increased the ductility so that cracking was avoided during the bend test.

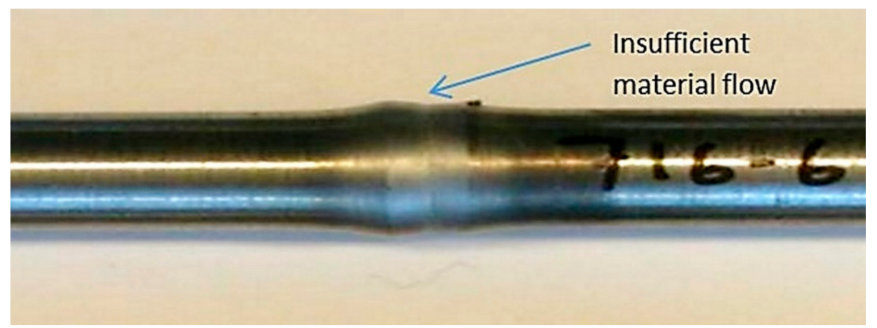

Figure 11. Insufficient material flow in the outer weld cap of the pipe that was welded at $950{ }^{\circ} \mathrm{C}$ (W3), resulting in a camel shaped outer cap.

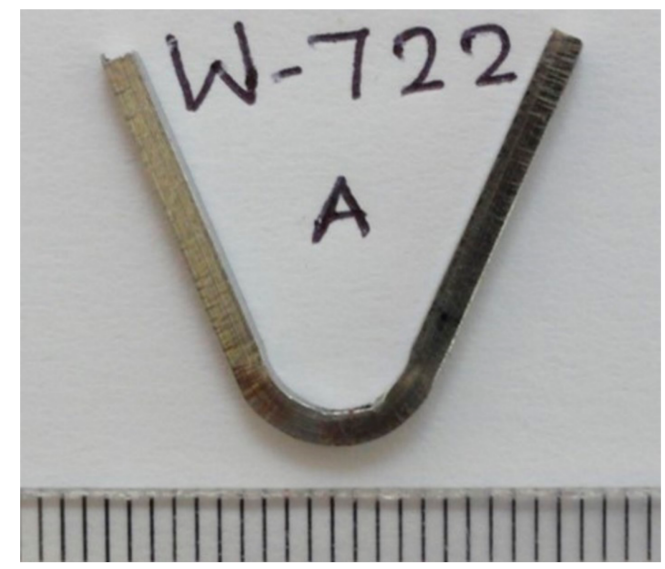

Figure 12. Typical face bent specimen.

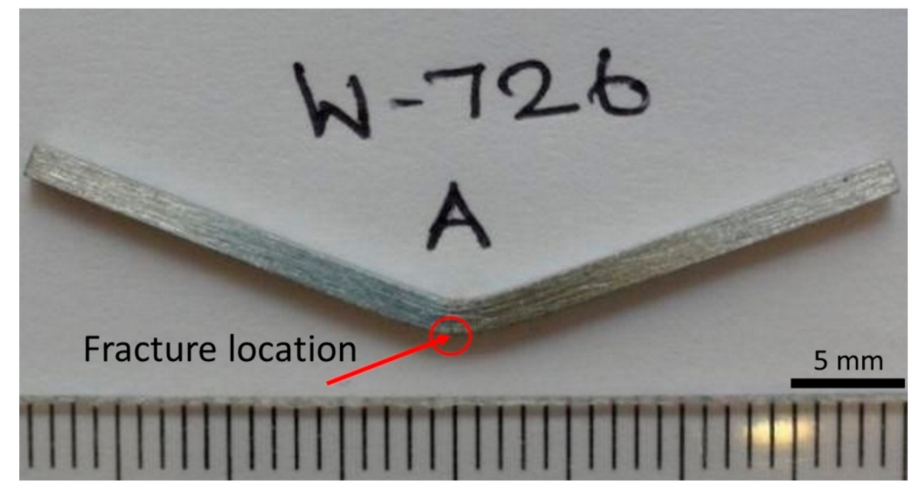

Figure 13. Fractured bend test specimen, forged welded at $1300^{\circ} \mathrm{C}$ followed by cooling at $10{ }^{\circ} \mathrm{C} / \mathrm{s}$ (W4).

\subsection{Toughness of Weld Zone}

Charpy V-notch values obtained at $0{ }^{\circ} \mathrm{C}$ for the small scale (miniature) forge welded specimens are given in Table 3. Conversion of miniature specimen values into full size values is not available, but Table 3 contains instead a comparison with the full size Charpy V values reported by the present authors in ref. [14] for specimens that were thermally simulated in a SMITWELD simulator at the same temperature conditions as welds W1-W11. There is no 
one-to-one correspondence between the two sets of Charpy values, but the thermal conditions that resulted in the most brittle miniature forge weld (W4), did also by far give the most brittle thermally simulated (full size) specimen. The weld zone of W4 had a hard microstructure of untempered martensite and bainite, which is the cause of the low toughness value of this weld. The largest difference between the two types of toughness values appears for the temperature cycle applied to weld W3, i.e., forging temperature $950^{\circ} \mathrm{C}$ followed by slow cooling at $1{ }^{\circ} \mathrm{C} / \mathrm{s}$, giving a relatively fine-grained polygonal ferrite/pearlite microstructure. Even though the SMITWELD specimen simulated at this condition had the highest toughness of them all, the forge welded specimen W3 had the next lowest toughness of them all. Probably, the low forging temperature of $950{ }^{\circ} \mathrm{C}$ resulted in high material flow stress and insufficient material flow during the forge welding process, resulting in low impact toughness, see also Figure 11 that shows an undercut in the outer weld cap of the W3 specimen. The small scale welds forged at $1150{ }^{\circ} \mathrm{C}(\mathrm{W} 2, \mathrm{~W} 8, \mathrm{~W} 10$ and $\mathrm{W} 11)$ possessed the highest Charpy values, probably because of the finer microstructures formed after forging at $1150{ }^{\circ} \mathrm{C}$ than after forging at the higher forging temperature $1300{ }^{\circ} \mathrm{C}$.

Table 3. Impact toughness obtained at $0{ }^{\circ} \mathrm{C}$ for small scale forge welded specimens and full size SMITWELD thermally simulated specimens. The values for the thermally simulated specimens are taken from Ref. [14], except for the values given for the conditions corresponding to W5, W6 and W10. These values were obtained during the present work. Two specimens were tested for each condition, and for the forge welded specimens the table gives average values and deviation to either side.

\begin{tabular}{ccc}
\hline Weld ID & $\begin{array}{c}\text { Charpy Values of Small Scale } \\
\text { Forge Welded Specimens [J] }\end{array}$ & $\begin{array}{c}\text { Charpy Values of Thermally } \\
\text { Simulated Full Size Specimens [J] }\end{array}$ \\
\hline W1 & $0.83 \pm 0.03$ & 27 \\
\hline W2 & $0.98 \pm 0.06$ & 65 \\
\hline W3 & $0.65 \pm 0.06$ & 164 \\
\hline W4 & $0.29 \pm 0.05$ & 8 \\
\hline W5 & $0.91 \pm 0.16$ & 52 \\
\hline W6 & $0.86 \pm 0.21$ & 57 \\
\hline W7 & $0.91 \pm 0.11$ & 84 \\
\hline W8 & $1.01 \pm 0.01$ & 103 \\
\hline W9 & $0.67 \pm 0.06$ & 109 \\
\hline W10 & $0.97 \pm 0.03$ & 151 \\
\hline W11 & $1.08 \pm 0.14$ & \\
\hline
\end{tabular}

Charpy testing at $0{ }^{\circ} \mathrm{C}$ was also performed on miniature specimens that had been extracted from SMITWELD specimens that had been thermally simulated to a peak temperature of $1300^{\circ} \mathrm{C}$ and cooled at different rates during the work reported in Ref. [14]. Figure 14 gives a comparison of the obtained miniature Charpy values and the corresponding full size Charpy values given in Ref. [14]. It is seen that the toughness values of the two sets of specimens roughly follow the same trend. Despite the more plain stress experimental condition for the small size samples, the shapes of the two graphs in Figure 14 are similar, showing that small scale toughness testing gives useful experimental results. 


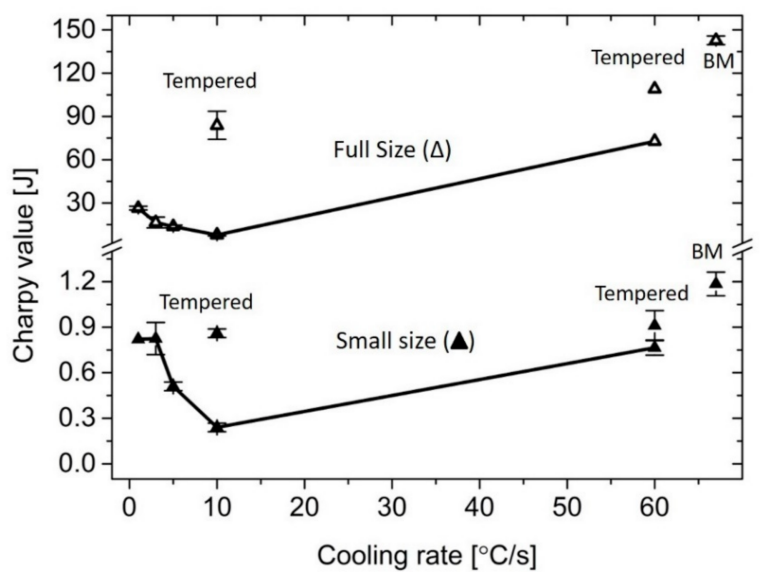

Figure 14. Comparison of $0{ }^{\circ} \mathrm{C}$ Charpy $\mathrm{V}$ values of full size (3 parallels) and miniature size (2 parallels) SMITWELD thermally simulated specimens. The peak temperature during the simulations was $1300^{\circ} \mathrm{C}$, and cooling was done as described in Section 2. Each graph includes two specimens that had been tempered for $1 \mathrm{~s}$ at $680^{\circ} \mathrm{C}$ after having been cooled at respectively $10^{\circ} \mathrm{C} / \mathrm{s}$ and $60{ }^{\circ} \mathrm{C} / \mathrm{s}$ from $920^{\circ} \mathrm{C}$. Base metal values are also given. The full size values are taken from Ref. [14].

From Figure 14 it is seen that the full size thermally weld simulated specimens that had been cooled from $1300^{\circ} \mathrm{C}$ at a rate of $60^{\circ} \mathrm{C} / \mathrm{s}$, possessed a higher toughness than the specimen that had been cooled at $1{ }^{\circ} \mathrm{C} / \mathrm{s}$. In Ref. [14] this is related to the difference in microstructure of the two specimens. The microstructure of the specimen cooled at $1{ }^{\circ} \mathrm{C} / \mathrm{s}$ consisted of a very coarse mixture of Widmanstätten ferrite and pearlite, both being brittle constituents, while the microstructure in the specimen cooled at $1{ }^{\circ} \mathrm{C} / \mathrm{s}$ consisted of martensite that might have gone through some self-tempering below the $\mathrm{M}_{\mathrm{s}}$ temperature $\left(392{ }^{\circ} \mathrm{C}\right)$.

If we had made graphs corresponding to those in Figure 14 for full scale and small scale forge welded specimens, these graphs would probably have resembled those in Figure 14. The only difference in experimental conditions would have been the forging step prior to specimen cooling, resulting in deformation induced recrystallization of the austenite and refined and tougher room temperature microstructures of the forge welded specimens. The two FW graphs would therefore probably have been lifted somewhat above those in Figure 14, and probably there would have been some local differences in slope. But it is expected that the two sets of graphs would have been similar to each other.

Table 4 gives some support to the idea that the weld zone of a forge welded specimen is somewhat tougher than a SMITWELD specimen thermally simulated at corresponding thermal conditions. The table gives toughness values for weld zones of SSFW specimens and corresponding small scale SMITWELD specimens. The first three rows in the table indicate higher toughness of the SSFW specimens, but the differences in average value are too small, and the scatter is too large to serve as a proof. (The toughness value of weld W9 in Table 4 distinguishes from the other values. From the microstructure images of welds W7 and W9 (Figure 6e,f), it is difficult to understand why W9 has a lower toughness than W7. It might be due to experimental scatter outside the range given in the table).

Although the cooling rate dependency is similar for the two graphs in Figure 14, the detailed correlation between them is far from an easy one. The full scale values cannot be deduced from the small scale values in an obvious way. For instance, the ratio $\mathrm{R}$ between full scale and corresponding small scale values varies very much along the graphs. Roughly, the trend is that $\mathrm{R}$ increases with increasing toughness, being 20-33 for the four specimen couples having the lowest Charpy values on the graphs to the left in Figure 14, and 95-124 for the other couples possessing higher Charpy values (including tempered specimens and base metal). As a comparison, the ratio between the specimen cross sections minus notch is about 44 , which ideally would be the scaling factor between full scale and small scale values if other differences in experimental conditions did not 
matter. The ratio between the cross section areas (about 44) has a value between the $\mathrm{R}$ ratios of the most brittle specimens and the toughest specimens, and this indicates that the small scale toughness tests have overestimated the toughness of the most brittle specimens and underestimated the toughness of the tougher specimens. Three factors associated with the experimental setup may have contributed to this result. First, specimen size affects the constraint of the notch during deformation. This means that the amount of plane strain and plane stress at the notch is significantly different for the two specimen dimensions. A smaller specimen experiences more plane stress conditions (i.e., lower constraint). Another aspect that probably has affected the correlation between the specimen sizes is the width of the specimen fixture during the testing, i.e., the anvil gap of the test machine. This has not been scaled, as the smaller specimens have a significantly larger ratio between the outer anvil gap $(20 \mathrm{~mm})$ and the specimen height than what is the case in the standard Charpy setup (45 $\mathrm{mm}$ anvil gap). Third, the strain rate at the notch tip is different for the two pendulum test machines. A standard Charpy machine has around $5.5 \mathrm{~m} / \mathrm{s} \mathrm{impact}$ speed. The small-scale machine used in this work has an impact speed of $3.8 \mathrm{~m} / \mathrm{s}$. A reduced speed increases the measured toughness. Of these three factors, the effect of the constraint is considered to have had the largest influence on the obtained results. So, the experimental circumstances around the toughness testing have been very complicated, and it is outside the scope of this work to analyse and explain the obtained toughness results in detail. However, assuming that the full-size toughness values are the more true ones, it can be concluded that the obtained small scale toughness values for miniature specimens are too high in the low ductility range and too low in the high ductility range. Probably, it is the small size effect on the ratio between plain strain and plain stress at the notch that is most responsible for this result.

Table 4. Small size Charpy values of forge welded specimens and thermal simulated specimens. Two specimens were tested for each condition, and the table gives average values and deviation to either side. (Welded specimens were quenched at a rate of $45^{\circ} \mathrm{C} / \mathrm{s}$, thermally simulated specimens were quenched at a rate of $60^{\circ} \mathrm{C} / \mathrm{s}$ ).

\begin{tabular}{ccc}
\hline $\begin{array}{c}\text { Forging Temperature + Cooling } \\
\text { Rate + Tempering }\end{array}$ & $\begin{array}{c}\text { Charpy Values of Small Scale } \\
\text { Forge Welded Specimens } \\
\text { [J] }\end{array}$ & $\begin{array}{c}\text { Charpy Values of Small Scale } \\
\text { Thermally Simulated Specimens } \\
\text { [J] }\end{array}$ \\
\hline $1300{ }^{\circ} \mathrm{C}+1{ }^{\circ} \mathrm{C} / \mathrm{s}(\mathrm{W} 1)$ & $0.83 \pm 0.03$ & $0.82 \pm 0.00$ \\
\hline $1300{ }^{\circ} \mathrm{C}+10^{\circ} \mathrm{C} / \mathrm{s}(\mathrm{W} 4)$ & $0.29 \pm 0.05$ & $0.24 \pm 0.02$ \\
\hline $1300^{\circ} \mathrm{C}+10^{\circ} \mathrm{C} / \mathrm{s}+680 / 1 \mathrm{~s}(\mathrm{~W} 7)$ & $0.91 \pm 0.11$ & $0.86 \pm 0.02$ \\
\hline $1300{ }^{\circ} \mathrm{C}+45(60)^{\circ} \mathrm{C} / \mathrm{s}+680 / 1 \mathrm{~s}(\mathrm{~W} 9)$ & $0.67 \pm 0.06$ & $0.91 \pm 0.07$ \\
\hline
\end{tabular}

Another factor that is not connected to the experimental setup, but which may have contributed to a scatter in toughness values obtained during the small-scale testing, might be the specimen grain size relative to the specimen thickness. The thermally simulated specimens of Figure 14 had been heated to a peak temperature of $1300{ }^{\circ} \mathrm{C}$, and at this high temperature they obtained an average austenite grain size of $80 \mu \mathrm{m}$ [14]. This implies that the remaining specimen thickness inside the notch of the tested miniature specimen only covered a distance of 15 prior austenite grains, which may not represent the average microstructure of the weld zone. This should at least have had an influence on the experimental scatter.

To summarize, it is evident that the small scale toughness tests of the weld simulated specimens do not provide data for reliable estimates of the true toughness of full size specimen volumes (e.g., by multiplying the small scale values by the ratio between the cross section areas). They only provide trends of how the toughness varies with the thermal conditions during the weld simulations (i.e., cooling rate). Of course, this relation between small scale and full-scale toughness testing would also apply to toughness testing of forge welded specimens. The toughness values given in Table 3 cannot be used to obtain true 
toughness values for real forge welds, but the values represent important trends and can be applied to obtain promising welding parameters for full scale SAG-FW welding.

From Table 3, it is seen that the only full size SMITWELD specimens that did not satisfy the API 5CT toughness requirement of $27 \mathrm{~J}$ with a good margin, are the specimens that were given the same temperature exposures as the forge welded specimens W1 and W4 (giving coarse microstructures of grain boundary ferrite, Widmanstätten ferrite and pearlite (W1), and untempered martensite/bainite (W4)). Table 3 shows relatively high toughness values for the other thermally weld simulated specimens, may be with exception of weld W3 $(0.65 \mathrm{~J})$ and weld W9 $(0.67 \mathrm{~J})$. Due to the similarity between the full size and small scale toughness of the SMITWELD specimens in Figure 14, and partly due to the (not well documented) similarity between the small scale toughness values of forge welded and thermally simulated specimen in Table 4 , it is fairly reasonable to assume that all welds except welds W1, W4, W3 and W9 probably satisfy the API 5CT toughness requirement with a good margin Welds W3 and W9 are questionable and would require more testing. (However, of other reasons that are reported in previous sections, they can be excluded from further evaluation due to, respectively, bad weld cap (Figure 11) and too high hardness (Figure 9)).

\subsection{Summary of Mechanical Tests}

To sum up the results from the mechanical testing, only weld W5 fully satisfies the API 5CT requirements for the L80 casing steel. Welds W2, W6 and W8 satisfy the ductility and probably also the toughness requirement, but they slightly fail the hardness demands. W2 and W6 are slightly too soft in a part of the heat affected zone, and W8 is slightly too hard in the weld zone. Welds W2 and W6 can probably be brought within the hardness requirements by slightly increasing the final cooling rate from $1{ }^{\circ} \mathrm{C} / \mathrm{s}$ or by decreasing the reheating temperature below $950^{\circ} \mathrm{C}$. Likewise, the weld zone hardness of W8 may easily be reduced to a value within the requirement by increasing the holding time at the post weld heat treatment temperature $680^{\circ} \mathrm{C}$. Weld W1 is also promising since it practically fulfils the hardness requirements, and its SSFW Charpy V value of $0.83 \mathrm{~J}$ is probably satisfactory high. But weld W1 requires a closer evaluation since the full size Charpy V toughness of the thermally simulated specimens corresponding to this weld only barely passed the minimum toughness requirement of $27 \mathrm{~J}$. However, the toughness of a full size SAG-FW weld produced by the welding parameters of weld W1 will probably be tougher than the SMITWELD specimens due to the forging step, which causes deformation induced recrystallization and grain refinement. So it is probable that also weld W1 fulfils the API $5 \mathrm{CT}$ requirements. All the other welds fail the requirements by a clear margin.

The validity of the above and previous discussions of the hardness results, does to some degree depend on the cooling rate as a function of HAZ temperature being equal during SSFW and full-size FW welding. The final microstructures and hardness values depend on both maximum temperature and cooling rate. Further studies need to be carried out to confirm this.

The mechanical tests also document that SSFW tests provide an effective tool for establishing welding parameters for full size SAG-FW welding. Within a single specimen, the method provides microstructure and hardness information along the whole weld width, including HAZ. It must be confirmed, however, whether HAZ locations that have been heated to the same maximum temperature during full scale and small scale forge welding, experience the same succeeding cooling rate. The final microstructure and mechanical properties depend both on maximum temperature and cooling rate. The toughness values that are obtained from SSFW testing do not provide values that are directly applicable to an actual full-size weld due to the small size of the SSFW specimens, being limited by the pipe wall thickness of the investigated pipe. The SSFW toughness values that were obtained by the small-scale machine used in the present work seem to be too high for microstructures of low toughness and too low for microstructures of high toughness. However, the trends in the SSFW toughness results seem to be realistic, and this trend can be utilized in the 
development of welding parameters for real welds. It might be an idea to examine to which degree small size FW toughness values can be converted into full-size values by applying the ratios $\mathrm{R}$ that can be extracted from Figure 14. (A plot of $\mathrm{R}$ as a function of small size (Smitweld) toughness could be made and applied to convert SSFW toughness values into full size FW toughness values.) At least, such a conversion should give an indication of full-size toughness values. Finally, it should be mentioned that toughness tests need to be carried out for critical parts of the heat affected zones in addition to the weld zone.

\subsection{General Corrosion Properties}

Immersion corrosion tests were performed on the welds that had the most promising mechanical properties, i.e., W1, W2, W5, W6 and W8. The first four of these welds had been cooled from austenite temperatures at a rate of $1{ }^{\circ} \mathrm{C} / \mathrm{s}$ as the final welding step and contained a variety of ferrite/pearlite microstructures in the central weld zone. Weld W1 had a Widmanstätten ferritic-pearlitic microstructure in the central weld zone, while the ferrite in W2, W5 and W6 was mainly polygonal. During the corrosion tests, these welds suffered heavier corrosion than the base metal in either the entire weld zone, W1 and W2, or in parts of the weld zone, W5 and W6. Figure 15 shows the depth topography graph of the corroded surface of weld W1. In the scanned IFM image at the top of the figure, the flow lines of the weld microstructure can clearly be seen after the specimen had been rinsed in running water. The position of the weld line is indicated by the thick vertical line in the below topography graph that was recorded along the thick line in the IFM image. A relatively even and symmetric corrosion attack is seen to have taken place within the entire weld zone (the base metal begins about $9 \mathrm{~mm}$ on either side of the weld line). The corrosion depth is seen to be in the range 1-3 $\mu \mathrm{m}$ with some deep pits.
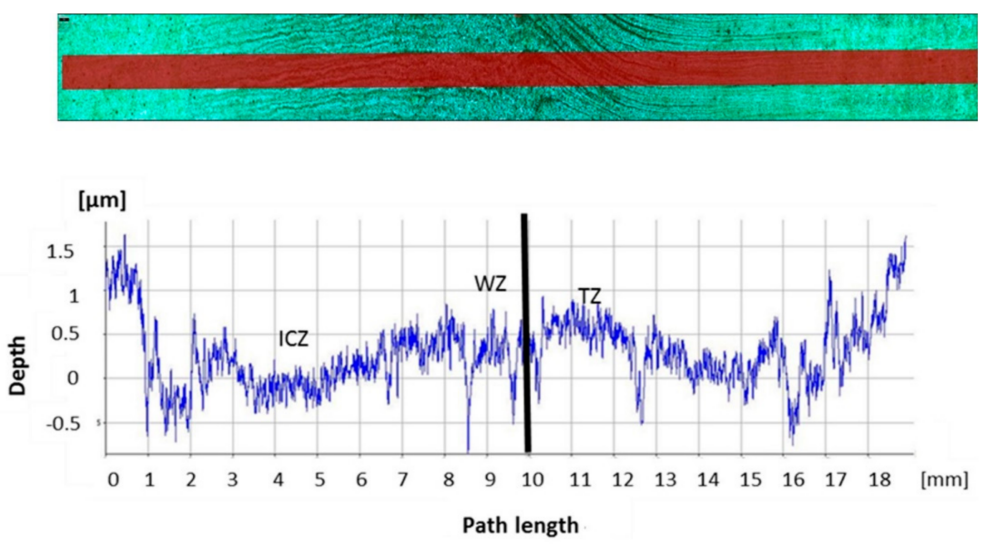

Figure 15. IFM scanned image (top) and topography analysis (bottom) of corroded specimen W1.

Weld W8 that had been cooled at $10{ }^{\circ} \mathrm{C} / \mathrm{s}$ from $1150{ }^{\circ} \mathrm{C}$ and afterwards tempered, had suffered very little corrosion in the weld zone, see Figure 16. The weld zone in this case was, in fact, less corroded than the tempered martensitic base metal which, according to the hardness profile in Figure 10, starts about $7 \mathrm{~mm}$ from the weld line (to confirm the high corrosion resistance of weld W8, a supplementary corrosion test was performed on weld W7 that had been processed with the same parameters as W8 except for a higher welding temperature $\left(1300^{\circ} \mathrm{C}\right)$. Weld W7 possessed almost identical corrosion properties to W8).

To conclude, of the welds that possess the most promising mechanical properties, weld W8 is the one that has the highest corrosion resistance, even superior to the base metal. This weld has mainly a tempered martensitic/bainitic microstructure after having been rapidly cooled from the welding temperature and subsequently post weld heat treated. The other welds with promising mechanical properties had ferrite/pearlite microstructures and poorer corrosion properties than the base metal. 


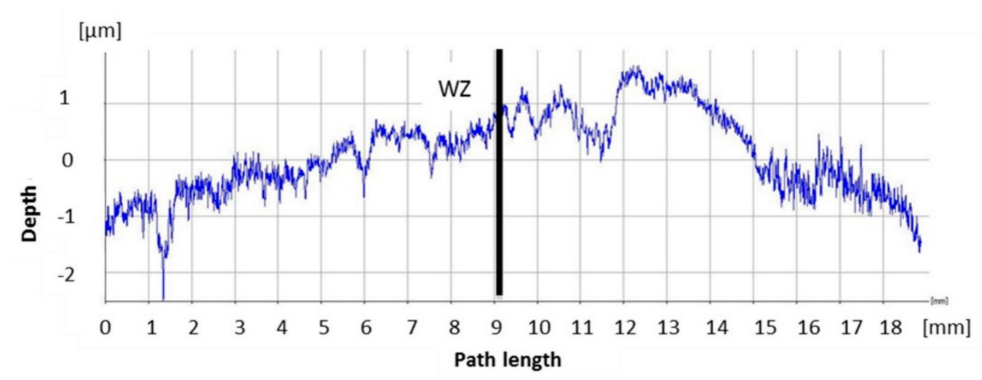

Figure 16. IFM topography analysis of corroded specimen W8. (There is no correlation between the depth values in Figures 15 and 16 since there was no common reference surface during the recordings).

The difference in corrosion resistance between the tested welds might be associated with the homogeneity of their microstructure. Welds W8 and W7 had a microstructure consisting mainly of ferritic constituents, i.e., grain boundary ferrite, bainite and tempered martensite, the latter two being ferrite with a distribution of small carbides. The other and less corrosion resistant welds had, on the microscale, a heterogeneous microstructure of ferrite grains and a high-volume fraction of perlite colonies. The electric contact between alternating layers of $\mathrm{Fe}_{3} \mathrm{C}$ and ferrite in the pearlite, may have caused galvanic corrosion of the pearlite in electrolytic environments, involving anodic dissolution of the ferrite phase. J. Dong et al. describe this phenomenon in Ref. [24].

\subsection{Final Remarks}

The welds W2, W5, W6, W8, and maybe W1, completely or nearly completely fulfilled the API 5CT requirements for mechanical properties. All of these welds except W8 contained ferrite/pearlite in both the weld zone and in the soft zone about $5 \mathrm{~mm}$ from the weld line. In addition to barely or not quite meeting the minimum hardness requirement of $204 \mathrm{HV}$, these welds also seem to have poorer corrosion properties than the base metal. Weld W8 therefore stands out as the most promising weld since its maximum hardness was only slightly higher than the maximum limit of $254 \mathrm{HV}$, and since its corrosion properties were better than those of the base metal. It is assumed that a slight adjustment of the welding procedure will bring the hardness within the API 5CT requirement, e.g., by slightly increasing the holding time during the post weld heat treatment. The welding procedure for W8 is also beneficial to procedures that involve low cooling rates to assure ferritic/pearlitic microstructures. Cooling rates of $1{ }^{\circ} \mathrm{C} / \mathrm{s}$ is not cost and time effective in field applications. A long cooling time will eliminate the advantages gained by a fast heating and forging step. Further development of the forge welding technique on L80 steel should therefore concentrate on optimizing the W8 welding procedure.

\section{Conclusions}

In order to develop a procedure for SAG-FW welding of an L80 grade pipe steel, satisfying the API 5CT requirements and in addition gives satisfactory corrosion resistance, miniature pipes were machined from large scale pipe walls and forge welded in a small scale forge welding machine at temperatures $1300^{\circ} \mathrm{C}, 1150{ }^{\circ} \mathrm{C}$ and $950{ }^{\circ} \mathrm{C}$, in some cases followed by post weld heat treatment. All welds were investigated with respect to cap geometry, internal oxide film formation, microstructure, and mechanical and corrosion properties. The most important experimental results can be summed up as follows:

(1) Acceptable weld caps were obtained for pipes welded at the two highest forging temperatures $1300{ }^{\circ} \mathrm{C}$ and $1150{ }^{\circ} \mathrm{C}$. A forging temperature of $950{ }^{\circ} \mathrm{C}$ produced an un-acceptable outer cap with a large undercut.

(2) No oxide film was detected at the weld line by WDS microanalysis.

(3) Larger grain sizes were observed for higher forging temperatures than for lower forging temperatures. A slow cooling at $1{ }^{\circ} \mathrm{C} / \mathrm{s}$ after forging produced a ferriticpearlitic microstructure. Faster cooling rates of $10^{\circ} \mathrm{C} / \mathrm{s}$ and $45^{\circ} \mathrm{C} / \mathrm{s}$ produced mixed microstructures of ferrite, martensite and possibly bainite in the weld zone. 
(4) Tempering at $680{ }^{\circ} \mathrm{C}$ for $1 \mathrm{~s}$ was sufficient to produce tempered martensite in the weld zone.

(5) Only the tested weld parameters that include post weld heat treatment, produced microstructures that completely satisfied the minimum and maximum hardness requirements throughout the heat affected zone. However, a cooling rate of $1{ }^{\circ} \mathrm{C} / \mathrm{s}$ following welding at $1300{ }^{\circ} \mathrm{C}, 1150{ }^{\circ} \mathrm{C}$ and $950{ }^{\circ} \mathrm{C}$ produced hardness values that closely satisfied the hardness requirements.

(6) Tempering at $680{ }^{\circ} \mathrm{C}(1 \mathrm{~s}$ or $300 \mathrm{~s})$ did not bring any of the tested welds within the acceptable hardness window, but the maximum hardness of the weld that was produced at $1150{ }^{\circ} \mathrm{C}$ followed by cooling at $10^{\circ} \mathrm{C} / \mathrm{s}$ and tempering at $680^{\circ} \mathrm{C}$ for $1 \mathrm{~s}$ was only slightly above the maximum hardness requirement. Only a small adjustment of the welding parameters (e.g., increased tempering time) would probably bring the entire hardness profile of this weld within the hardness requirement.

(7) A secondary heat treatment cycle consisting of heating at $950{ }^{\circ} \mathrm{C}$ for $1 \mathrm{~s}$ followed by subsequent cooling at $1{ }^{\circ} \mathrm{C} / \mathrm{s}$ was applied to the weld produced at $1300{ }^{\circ} \mathrm{C}$ followed by rapid cooling at $45^{\circ} \mathrm{C} / \mathrm{s}$, and brought the hardness profile of this weld completely within the required hardness window.

(8) With one exception, all welding parameters gave high or medium high toughness values, which seems very promising. Only the weld that was forged at $1300{ }^{\circ} \mathrm{C}$ followed by $10{ }^{\circ} \mathrm{C} / \mathrm{s}$ cooling failed the toughness requirements.

(9) The main impression from the immersion corrosion tests was that tempered martensite in general gave good corrosion resistance, probably due to a homogeneous microstructure, and that ferrite/pearlite gave poorer corrosion resistance due to anodic dissolution of ferrite. All welds corroded more than the base metal except the two welds that were cooled at $10{ }^{\circ} \mathrm{C} / \mathrm{s}$ after forging at $1300{ }^{\circ} \mathrm{C}$ and $1150{ }^{\circ} \mathrm{C}$ and subsequently tempered at $680^{\circ} \mathrm{C}$ for $1 \mathrm{~s}$.

The main conclusion that can be drawn from the above list of specific results is that forging at high temperature followed by rapid cooling and a short temper at high temperature (giving mainly a tempered martensitic microstructure) is probably the most favourable procedure for SAG-FW welding of an L80 grade pipe steel for oil well application. In addition to giving acceptable weld properties, a welding procedure that involves high cooling rates and an extremely short tempering time is also beneficial from a cost- and time effective point of view. More specific, in the present study, welding parameters including forging at $1150{ }^{\circ} \mathrm{C}, 10^{\circ} \mathrm{C} / \mathrm{s}$ cooling rate, and tempering at $680^{\circ} \mathrm{C}$ for $1 \mathrm{~s}$ gave the most promising weld properties including cap geometry, oxide film formation at the weld line, hardness, toughness, and corrosion resistance. However, the parameters need to be slightly tuned to give hardness values completely within the API 5CT requirements, and full scale welding needs to be done to confirm the findings.

Another important conclusion is that small scale forge welding provides a very useful tool in the development of welding parameters for full size SAG-FW welding. How the cooling conditions in the heat affected zone compare during full scale and small scale forge welding, needs, however, to be studied. And one must also bear in mind that small scale toughness testing seems to overestimate the toughness of specimens in the low toughness range and underestimate the toughness of specimens in the high toughness range.

Author Contributions: Conceptualization, V.P., J.K.S. and P.T.M.; Formal analysis, V.P., J.K.S. and P.T.M.; Funding acquisition, J.K.S. and P.T.M.; Investigation, V.P.; Methodology, V.P., J.K.S. and P.T.M.; Project administration, J.K.S.; Resources, J.K.S. and P.T.M.; Supervision, J.K.S.; Writing-original draft, V.P., J.K.S. and P.T.M.; Writing-review \& editing, V.P., J.K.S. and P.T.M. All authors have read and agreed to the published version of the manuscript.

Funding: The research work was carried out as a $\mathrm{PhD}$ project funded by Faculty of Natural Sciences, Norwegian University of Science and Technology (NTNU). Additional funding of experimental work was given by AMR Engineering AS, Drammen, Norway, and by Tube Fuse Technology Ltd., UK. The APC was funded by Norwegian University of Science and Technology. 
Data Availability Statement: Data sharing is not applicable to this article.

Acknowledgments: The authors are grateful to Nuria Espallargas from Department of Mechanical and Industrial Engineering, NTNU, for her assistance in conducting corrosion experiments, and to Hans Iver Lange, Department of Materials and Nanotechnology, SINTEF Industry, for his assistance during toughness testing, including valuable discussions. Sincere thanks are also due to Pål Skaret and Pål Ulseth, both Department of Materials Science and Technology, NTNU, for their assistance in carrying out ductility tests and sample preparation, respectively.

Conflicts of Interest: The authors declare no conflict of interest. The industrial sponsors had no role in the design, execution, interpretation, or writing of the study.

\section{References}

1. Messeler, R.W. Principles of Welding: Process, Physics, Chemistry and Metallurgy; John Wiley \& Sons, Inc.: New York, NY, USA, 1999.

2. AWS Welding Handbook, Resistance and Solid State Welding and Other Joining Processes, 7th ed.; American Welding Society: Miami, FL, USA, 1980; Volume 3.

3. Kong, T.F.; Chan, L.C.; Lee, T.C. Qualitative study of bimetallic joints produced by solid state welding process. Sci. Technol. Weld. Join. 2008, 13, 679-682. [CrossRef]

4. AWS Welding Handbook, Welding Processes: Arc and Gas Welding and Cutting, Brazing and Soldering, 7th ed.; Kearns, W.H. (Ed.) American Welding Society: Miami, FL, USA, 1978; Volume 2.

5. Zheng, S.; Wu, Q.; Huang, Q.; Liu, S.; Han, Y. Influence of different cooling rates on the microstructure of the HAZ and welding CCT diagram of CLAM steel. Fusion Eng. Des. 2011, 86, 2616-2619. [CrossRef]

6. Hattingh, R.J.; Pienaar, G. Weld HAZ embrittlement of Nb containing C-Mn steels. Int. J. Press. Vessel. Pip. 1998, 75, 661-677. [CrossRef]

7. Gharibshahiyan, E.; Raouf, A.H.; Parvin, N.; Rahimian, M. The effect of microstructure on hardness and toughness of low carbon welded steel using inert gas welding. Mater. Des. 2011, 32, 2042-2048. [CrossRef]

8. Du, W.; Zhao, L.; Tian, Z.; Peng, Y.; Xu, L. Mechanical Properties of Arc Welding Heat-Affected Zone of High Nitrogen Steel. J. Iron Steel Res. Int. 2007, 14, 263-267. [CrossRef]

9. Moe, P.H. Sammenføyingsmetoder Ved Rørlegging Til Havs. PhD. Thesis, Norwegian University of Science and Technology, Trondheim, Norway, 1987.

10. Ganesan, S.M. Small Scale Forge Welding, Process Design and Analysis. PhD. Thesis, Department of Engineering design and Materials, NTNU, Trondheim, Norway, 2013.

11. Moe, P.T.; Abtahi, S.; Ganesan, S.M.; Valberg, H.; Støren, S.; Rudd, W. Optimization of a pipe end upsetting process. Int. J. Mater. Form 2008, 1, 13-16. [CrossRef]

12. Ganesan, S.M.; Moe, P.T.; Salberg, B.; Audestad, J.I.; Valberg, H.; Rudd, W.; Burnell-Gray, J.S. Design of a small-scale hot forging test. Int. J. Mater. Form 2009, 2, 113-116. [CrossRef]

13. Ganesan, S.M.; Moe, P.T.; Vinothkumar, P.; Audestad, J.; Salberg, B.; Valberg, H.; Solberg, J.K.; Burnell-Gray, J.; Rudd, W. Establishment of heat treatment cycles for forge welded API L80 tubular joints. Int. J. Mater. Form 2010, 3, 343-346. [CrossRef]

14. Palanisamy, V.; Solberg, J.K.; Salberg, B.; Moe, P.T. Analysis of Weld Thermal Simulated API 5CT L80 Casing Grade Steel, Submitted to Welding in the World; Springer Nature: Cham, Switzerland, 2021.

15. Ellingsen, Ø.A. The Effect of Tempering and Normalizing on Steel Alloy L80. Master's Thesis, Department of Material Science and Technology, NTNU, Trondheim, Norway, 2009.

16. Casing and Tubing, API Specifications 5CT, 10th Edition. 2018. Available online: https://www.api.org/products-and-services/ standards/important-standards-announcements/standard-5ct (accessed on 27 January 2021).

17. BBS Stål \& Metaller, Hardness Conversion Table-Tensile Strength, Vickers, Brinell och Rockwell (according to DIN 50150). Available online: https:/ / www.bbshalmstad.se/en/infocenter/hardness-conversion-table (accessed on 27 January 2021).

18. EN 1011-2, 'Welding_Recommendations for Welding of Metallic Materials_Part 2: Arc Welding of Ferritic Steels'; iTeh, Inc.: Newark, DE, USA, 2012.

19. Andrew, K.W. Empirical formulae for the calculation of some transformation temperatures. JISI 1965, 203, 721-727.

20. ASTM E 112, Standard Test Methods for Determining Average Grain Size; ASTM International: West Conshohocken, PA, USA, 2012.

21. ASTM E190, Standard Test Method for Guided Bend Test for Ductility of Welds; ASTM International: West Conshohocken, PA, USA, 2008.

22. Da Cruz Junior, J.A.; Santos, D.B. Effect of tempering temperature on isothermal decomposition product formed below Ms. Journal of Materials Research and Technology 2013, 2, 93-99. [CrossRef]

23. Line Pipe, API Specification 5L, 46th Edition. 2018. Available online: https://www.api.org/products-and-services/standards/ important-standards-announcements/standard-5l (accessed on 27 January 2021).

24. Dong, J.; Hao, X.; Wei, J.; Ke, W. Study on the galvanic corrosion of ferrite-pearlite steel and its control under acid environment. In Proceedings of the 3rd International Conference on Electrochemistry, Berlin, Germany, 10-11 July 2017. 